\title{
Phytic acid - its influence on organism
}

\author{
T. Szkudelski \\ Department of Animal Physiology and Biochemistry, \\ Poznań University of Agriculture \\ Wolyńska 35, 60-637 Poznań. Poland
}

(Received 6 June 1997; accepted 24 October 1997)

\begin{abstract}
Phytic acid is found in the grains and seeds of many plants. Its presence in the diet nay restrict the absorption of many major and trace elements from the digestive tract. The interactions of this compound with intestinal digesta compounds can reduce protein and starch digestibility. This leads to reduced nitrogen retention and causes a milder rise in glycemia during absorptive phase. Phytic acid also has antineoplastic properties, can prevent renal stone formation and some heart diseases. This compound is synthesized in mammalian tissues and its ability to bind specifically with some cellular proteins has been demonstrated.

In this paper an outline of the most important metabolic effects of phytic acid is presented. It is also attempted to explain some of the mechanisms of its action based on data from the literature.
\end{abstract}

KEY WORDS: phytic acid, metabolism

Phytic acid (inositol hexaphosphosphoric acid) is found in many vegetable products used in the nutrition of animals and consumed by humans. The grain and seeds of certain plants, and their products such as wheat bran, are particularly rich in this compound. The phytic acid content in grain and seeds differs considerably, and can reach a maximum of about $2 \%$ dry weight (Reddy, 1992).

The interference of phytic acid in metabolic processes begins even in the digestive tract, when it reacts with components of the intestinal contents.

The most frequently observed consequence of the presence of phytic acid is inhibition of the absorption of many major and trace elements from the digestive 
tract. This can lead to a deficit of minerals in the body. Since the problem of the effect of phytic acid on mineral metabolism has been the subject of numerous studies, the mechanism of this process is relatively well understood and has been characterized in several reviews (Maga, 1982; Wise, 1983; Harland and Oberleas, 1987; Szkudelski, 1995).

The objective of this paper is to present other, less known effects of phytic acid. It is also attempted to explain the mechanisms through which this compound affects metabolic processes.

An important practical aspect is the interference of phytic acid in digestion. One of the effects observed in many experiments is inhibition of protein degradation. This is related to the unique structure of phytic acid that allows it to bind with proteins in a wide range of $\mathrm{pH}$. In an acidic environment, when the $\mathrm{pH}$ is below the isoelectric point of a protein, bonds are formed between the negatively charged phosphate resuides of phytic acid and the positively charged amino groups of the amino acids composing the protein. Raising the $\mathrm{pH}$ changes the charge on the protein and the nature of the bonds. The negatively charged carboxyl residues of the protein bind with the negatively charged phosphate residues of phytic acid through multivalent metal cations (Cheryan, 1980).

The affinity of phytic acid to different proteins varies and depends on numerous factors (O'Dell and de Boland, 1976). These include the amino acid composition of the protein and the conformation of the protein molecule, which determines the accessibility of specific amino acid residues (O'Dell and de Boland,1976; Knuckles et al., 1985). The concentration of metal cations in the medium is also not without effect (Gifford and Clydesdale, 1990).

Binding of phytic acid to protein leads to the formation of complexes characterized by low solubility (O'Dell and de Boland, 1976; Cheryan, 1980; Scheuermann et al., 1988), and the protein in these complexes becomes less susceptible to degradation by proteolylic enzymes (Barre, 1956; Kratzer,1965; Knuckles et al., 1985).

As a result of different affinity of phytic acid to various types of proteins, the inhibitory effect of this compound on their digestibility is also not uniform. One example illustrating this is the effect of phytic acid on the digestion of bovine serum albumin and casein. The digestion of the former of these proteins is much less inhibited (Knuckles et al., 1985).

The interactions of phytic acid are not limited only to proteins ingested with food, but also apply to proteolytic enzymes. Under in vitro conditions it was observed that phytic acid inhibited trypsin activity (Singh and Krikorian, 1982; Caldwell, 1992). It is presumed that phylic acid binds with the calcium ions in the molecule of this enzyme, increasing its susceptibility to autolysis (Singh and Krikorian, 1982). Moreover, phytic acid can also inhibit the conversion of trypsinogen into trypsin. This process also seems related to the binding of 
calcium ions in the trypsinogen molecule. The presence of these ions is considered necessary for hydrolysis of the peptide bond in trypsinogen that converts it into the active form of this enzyme (Delaage and Lazdunski, 1967; Caldwell, 1992).

Poorer protein digestibility in the presence of phytic acid has often been observed in vitro, but this effect has been found in vivo too. A measurable consequence of this is the reduction of nitrogen retention in animals fed feeds containing phytic acid, as compared with animals fed diets from which phytic acid had been removed (Mroz et al., 1994; Nasi et al., 1995). Studies have also been reported in which no adverse effect of this compound on protein utilization had been found (Thompson and Serraino, 1986). These results may in part be explained by the complexity of the interactions in the digestive tract between phytic acid and proteins, especially in the presence of various concentrations of metal cations. The activity of phytases catalyzing the dephosphorylation of phytic acid to products that have a lesser effect on digestive processes may also vary. Moreover, it is known that the pancreas is able to increase the secretion of proteolytic enzymes in response to disturbances in protein digestion. Enzyme secretion by the pancreas occurs, among others, with the participation of cholecystokinin that regulates this process through a feed-back mechanism. This conclusion is supported by the results of experiments in which elevated cholecystokinin concentrations were found in the plasma of rats (Liddle et al., 1984) and humans (Calm et al., 1987) fed diets containing trypsin inhibitors. Restricting the digestion of protcin by phytic acid may thus affect the secretory activitics of the pancreas.

Protein is not, however, the only nutrient whose digestion can be affected by the presence of phytic acid, since it has been observed that this compound can also inhibit the digestion of starch (Deshpande and Cheryan, 1984; Sandberg et al., 1989; Sandberg et al., 1993). One of the reasons for the decreased degradation of the polysaccharide is the inhibitory cffect of phytic acid on $\alpha$-amylase. It seems that the effect of phytic acid on $\alpha$-amylase activity is not of a compctitive nature, but a consequence of its general ability to bind protein (Deshpande and Cheryan, 1984). Moreover, this compound can decrease $x$-amylase activity by chelating the calcium ions needed for its normal activity (Bouncore et al., 1976). It can also act directly on starch, as well as bind with the proteins linked to this polysaccharide (Yoon et al., 1983).

To a certain degree, phytic acid can also restrict food passage from the stomach to the intestines. It has been observed that compounds binding calcium decrease the stomach emptying rate (Sognen, 1965).

A consequence of the inhibitory effect of phytic acid on digestion of starch in the digestive tract is the lower increase in glycemia during the period of absorption (Yoon et al., 1983; Thompson et al., 1987). 


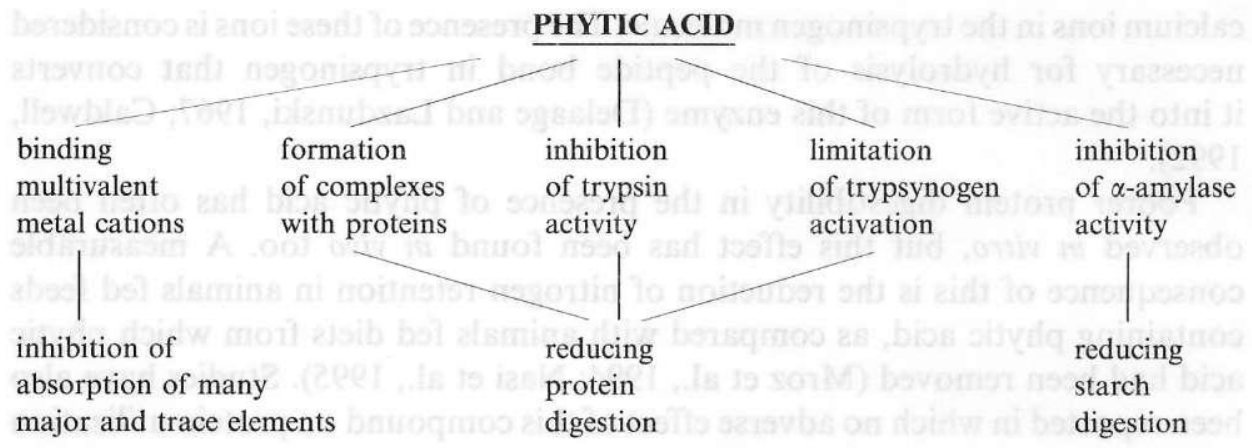

Diagram 1. Effects of phytic acid in the digestive tract

After adding phytic acid to food, a distinct negative correlation between its content in the diet and postprandial increases in blood glucose levels was noted. The opposite effect was also demonstrated: a sharper increase in glycemia after consuming food from which phytic acid had previously been removed (Thompson et al., 1987).

The smaller increase in postprandial glycemia seems to have positive effects. This is related to the fact that consuming foods containing only easily digestible polysaccharides that cause a steep jump in blood glucose levels requires the secretion of considerable amounts of insulin (Jenkins and Wolever, 1981). A high insulin level in the blood may desensitize cells to it, leading to insulin resistance (Jenkins and Wolever, 1981). The elevated level of insulin may also lead to higher blood triglyceride levels (Carlson et al., 1979). However, foods containing polysaccharides that are more slowly digested and absorbed may, in the case of hypertriglyceridemia, normalize the triglyceride level in blood, as well as lower total and low density lipoprotein cholesterol (Jenkins et al., 1985).

The effect of phytic acid on the rate of starch digestion and the postprandial increase in glycemia may be only slight as the result of binding some ions (especially $\mathrm{Ca}^{2+}$ ) that are present in sufficient amounts in the digestive tract contents (Yoon et al., 1983; Thompson et al., 1987).

The effects of phytic acid in the digestive tract are presented in Diagram 1.

The effects of phytic acid on metabolism are not limited only to the digestive tract. According to Modlin (1980), consuming this compound with food is an important factor restricting the formation of renal stones. This conclusion is based on observations of the frequency of renal stones in populations with differing dietary habits (Wise and Kark, 1961). Populations with diets containing a high level of inorganic phosphorus from animal sources had a significantly higher incidence of renal stones than groups of people who consumed high amounts of phosphorus in the form of phytic acid. 
One of the mechanisms by which phytic acid inhibits renal stone formation is related to the products of its hydrolysis in the digestive tract, which are then absorbed and excreted with urine. In vitro it was found that inositol di- and triphosphate prevent crystallization of hydroxyapatite, a molecule that triggers stone formation (Thomas and Tilden, 1972; Malek and Boyce, 1973). High concentrations of these compounds in urine may be a factor preventing renal stone formation (Modlin, 1980).

The risk of renal stone disease is also higher when the urine contains high levels of calcium. In this situation it is justified to reduce calciuria by decreasing calcium absorption from the digestive tract. This can be achieved by a lowcalcium diet or the administration of compounds decreasing calcium absorption. In one experiment, rice bran rich in phytic acid given to individuals with idiopathic hypercalciuria markedly decreased the amount of calcium excreted with urine. Removing phytic acid from the rice bran eliminated its beneficial effect (Ohkawa et al., 1983).

The inhibitory effect of phytic acid on the amount of calcium excreted with urine was also found in experiments on rats fed a diet rich in this element (Ohkawa et al., 1984).

In the case of a high calcium diet, products of phytic acid degradation are found in smaller amounts in the urine, but the excretion of phytic acid and the ions bound with it in faeces is increased. This is a result of its reduced degradation in the digestive tract (Nahapetian and Young, 1980). That is why it seems that in a situation in which the supply of calcium is increased in the diet, the inhibitory effect of phytic acid on renal stone formation results mainly from limiting calcium uptake in the digestive tract.

One of the most intriguing aspects of supplying phytic acid in the diet is its antineoplastic activity. This has been confirmed in many experiments (Menniti et al., 1992; Sakamoto et al., 1993; Vucenik et al., 1993, 1995; Shamsuddin and Yang, 1995), although the mechanism of its anti-cancer action is not well known. Observations showing that phytic acid is also effective not only in preventing cancer, but also in treating it, are interesting (Shamsuddin and Ullah, 1989).

In in vitro experiments it was observed that some cancer cells have a high ability to take up phytic acid from the incubation medium (Vucenik and Shamsuddin, 1994). It was found that phytic acid taken up by cancer cells can be a factor restricting their growth (Shamsuddin and Yang, 1995). The inhibitory effect of this compound on cell proliferation seems to be related to its intracellular activity that has an major impact on the metabolism and pool of messenger compounds in the cells (e.g. inositol phospholipids) (Shamsuddin and Yang, 1995). The phytic acid taken up by cells can also undergo changes that lead to alterations in the concentration of calcium ions in the cytoplasm (Shamsuddin et al., 1992). 
Many authors believe that the antineoplastic effects of phytic acid is related to its ability to restrict the availability of some elements that are necessary for cell proliferation. This applies mainly to zinc and magnesium (Jariwalla et al., 1988; Thompson and Zhang, 1991). A deficit of zinc would be a factor inhibiting many enzymes that are important for normal cell function. The activity of thymidine kinase, which is necessary for the replication of DNA and cell division, can be decreased after only six days of deficit of this element (Prasad and Oberleas, 1974).

Phytic acid may also counteract some of the adverse changes in a cell may thanks to its iron-binding ability. Iron ions catalyze the so-called Fenton reaction and contribute to the production of highly reactive hydroxyl radicals that damage DNA and initiate lipid peroxidation. Phytic acid is one of the chelating compounds that bind iron in a manner completely preventing the participation of these ions in the Fenton reaction (Graf and Emoson, 1987; Graf and Eaton, 1990).

In vitro studies have shown that phytic acid counteracts the harmful changes (fibrosis and inflammation of alveoli) occurring in rats subjected to the influence of asbestos. Phytic acid prevented these changes mainly by reducing the amount of hydroxyl radicals induced by the presence of this cancerogenic substance (Kamp et al., 1995).

The inhibitory effect of phytic acid on the development of cancer can also be observed when its administration begins even several months after treating an experimental animal with a cancerogenic substance (Shamsuddin and Ullah, 1989). This points to a greater complexity of the mechanisms of the antineoplastic action of this compound. This activity may encompass even such complex processes as growth and activation of NK lymphocytes observed under the influence of phytic acids in animals with induced cancer (Baten et al., 1989).

From the above data is seen that phytic acid may exert antineoplastic effects in various, mutually supportive ways. It seems very probable that the effects observed in in vivo experiments do not result only from its interference in processes occurring in the digestive tract. Although the inhibitory effect of phytic acid on the development of cancers of the digestive tract, especially the colon, has been observed in many experiments (Graf and Eaton, 1985; Nelson, 1992), there are also studies showing that phytic acid has beneficial effects on other organs too (Vucenik et al., 1993, 1995). This is undoubtedly related to the fact that phytic acid, or its dephosphorylation products, are absorbed from the digestive tract and are transported to many tissues and organs (Sakamoto et al., 1993). It is known that phytic acid is degraded in cells to $\mathrm{CO}_{2}$ that is eliminated in expired breath (Nahapetian and Young, 1980).

The antineoplastic effects of phytic acid are often more clearly visible when it is administered to animals with drinking water (Vucenik et al., 1993). In part this may be due to limiting its interaction with components of the diet. 
In 1987 Szwergold et al. used nuclear magnetic resonance to detect the presence of phytic acid in many mammalian tissues and assessed its amount with the range of 5-15 nmole/g fresh tissue (Szwergold et al., 1987). This lead to great interest arising in this compound, particularly in terms of its role in the body.

The effect of these studies was, among others, the discovery that phytic acid bound specifically to some cellular proteins. A receptor was found in central nervous system cells that bound inositol phosphates, including inositol hexaphosphate. This receptor showed potassium channel activity (Chadwick et al., 1992).

Another important observation was the discovery of specific binding of phytic acid by cytoplasm proteins referred to in abbreviation as AP-2 (Voglmaier et al., 1992) and AP-3 (Norris et al., 1995). These proteins play an important role in the formation of so-called clathrin cages in cells that participate in the endocytosis of ligand-receptor complexes. It was found that phytic acid had a higher affinity to binding AP-3 in comparison with less phosphorylated inositol phosphates (Norris et al., 1995). Binding inositol hexaphosphate with the above mentioned proteins distinctly inhibited the formation of clathrin cages in cells (Norris et al., 1995).

On the basis of these observations it is difficult, however, to unequivocally determine the exact effect of phytic acid on the nerve cell. Some more information on its role in the nervous system was provided by the results of experiments conducted by Valejo et al. (1987). In experiments on rats it was shown that phytic acid is synthesized from inositol in some structures of the central nervous system. The authors of the cited study suggest that its synthesis is locally regulated and may be dependent on local demand for this compound. It is assumed that phytic acid may, to a certain extent, participate in the regulation of central nervous system function. It was observed that microinjections of this compound into the solitary tract nuclei that participate in cardiovascular regulation, caused distinct bradycardia and hypotension in rats. This effect is reversible and related to the stimulation of a certain group of neurons, and its intensity depends on the amount of phytic acid administered into the central nervous system (Valejo et al., 1987).

In addition to its effects on the nervous system, this compound can also bind selectively with some proteins in the eye that participate in visual processes (Palczewski et al., 1991; Day et al., 1995).

Despite the above observations, the role of phytic acid in the cell is, at present, still little known and its elucidation requires further study.

There are suppositions that phytic acid plays an important role in preventing heart disease that develops as a consequence of lipid metabolism disorders. In experiments on animals it was found that enriching the diet with this compound markedly reduces blood cholesterol and triglyceride levels (Kleway, 1977; 
Jariwalla et al., 1990). This effect may be the result of the effect of phytic acid on the availability of some elements, particularly zinc and copper (Kleway, 1973, 1975). Moreover, the reduction in the level of triglycerides and cholesterol may also be a consequence of the effect of phytic acid on postprandial increases of glycemia. This effect was already mentioned earlier in this paper.

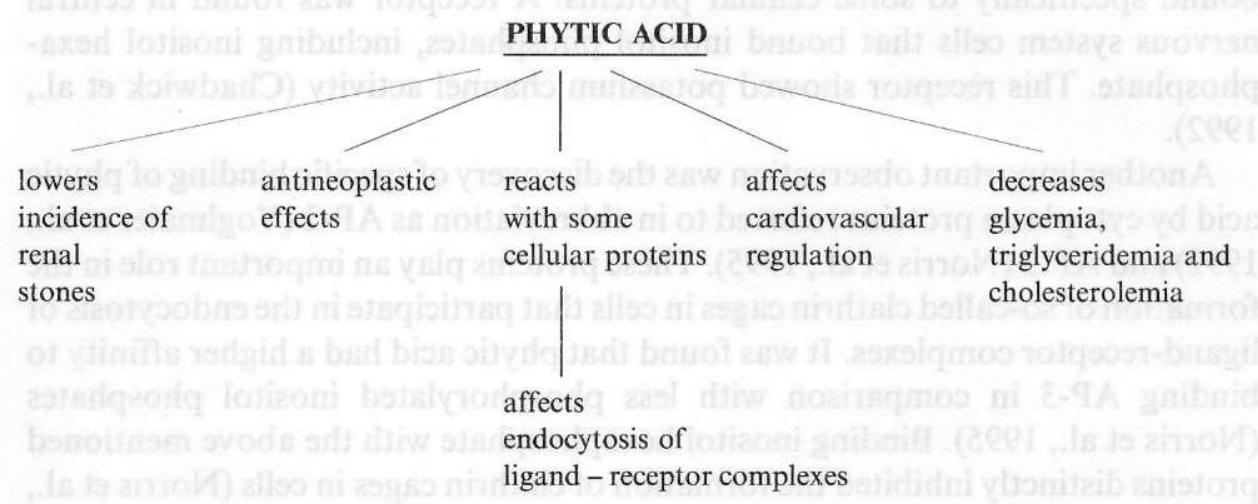

Diagram 2. Effects of phytic acid on the body

It is very probable that some of the effects observed as the result of increased dietary phytic acid supply are caused by compounds that arise through the partial or total dephosphorylation of phytic acid in the digestive tract. This is corroborated among others by observations showing that myo-inositol is a compound that causes a distinct drop in the level of triglycerides in the liver (Anderson and Holub, 1980).

The effects of phytic acid on the body are shown in Diagram 2.

It seems that the ubiquity of phytic acid in plant products used in feeding animals and consumed by humans should prompt more interest in this compound.

From the results of the studies mentioned above, it can be seen that phytic acid can often have a favourable effect on the body, but its action still remains little understood.

\section{REFERENCES}

Andersen D.B., Holub B.J., 1980. Myo-inositol-responsive liver lipid accumulation in the rat. J. Nutr. 110, 488-495

Barré M.R., 1956. Influence de l'acide phytique sur la digestion pepsique de differentes protéines.

Ann. Pharm. France 14, 182-186 
Baten A., Ullah A., Tomazic V.J., Shamsuddin A.M., 1989. Inositol-phosphatc induced enhancement of natural killer cell activity correlates with tumor suppresion. Carcinogenesis 10 , 1595-1599

Bouncore V., Poerio E., Silano.. Tomasi M.. 1976. Physical and catalytic properties of alpha amylase from Tenebrio molitor L. larvac. Biochem. J. 153, 621-625

Caldwell R.A., 1992. Effect of calcium and phytic acid on the activation of trypsinogen and the stability of trypsin. J. Agric. Food Chem. 40, 43-46

Calm J., Bojarski J.C., Springer C.J., 1987. Raw soya-bean flour increases cholecystokinin release in man. Brit. J. Nutr. 58, 175-179

Carlson L.A.. Bottiger L.E., Ahfeldt P.E., 1979. Risc factor for myocardial infarction in the Stockholm prospective study: A 14-year follow up focusing on the role of plasma triglyceride and cholesterol. Acta Med. Scand. 206, 351-360

Chadwick C.C., Timerman A.P., Saito A., Mayrleitner M., Schindler H., Flcischer S., 1992. Structural and functional characterisation of an inositol polyphosphate receptor from ccrebellum. J. Biol. Chem. 267, 3473-3481

Day N.S., Ghalayini A.J., Anderson R.E., 1995. Membrane-associated inositol hexakisphosphate binding in bovine retina. Curr. Eye Res. 14, 851-855

Delaage M., Lazdunski M., 1967. The binding of $\mathrm{Ca}^{2+}$ to trypsinogen and its relation to the mechanism of action. Biochem. Biophys. Res. Commun. 28, 390-394

Deshpande S.S., Cheryan M., 1984. Effects of phytic acid. divalent cations, and their interactions on x-amylase activity, J. Food Sci. 49, 516-519

Graf E., Eaton J.W., 1990. Antioxidant functions of phytic acid. Free Radical Biol. Med. 8, 61-69

Graf E., Empson K. L., 1987. Phytic acid. A natural antioxidant. J. Biol. Chem. 262, 11647-11650

Gifford S.R,, Clydesdale F.M.,1990. Interactions among calcium, zinc and phytate with three protein sources. J. Food Sci. 55,1720-1724

Harland B.F., Oberleas D., 1987. Phytate in foods. Wld. Rev. Nutr. Diet. 52, 235-259

Jariwalla R.J., Sabin R., Lawson S., Bloch D.A., Prender M., Andrews V., Herman Z.S., 1988. Effect of dietary phytic acid (phytate) on the incidence and growth rate of tumors promoted in Fisher rats by magnesium supplement. Nutr. Res. 8, 813-827

Jariwalla R.J., Sabin R., Lawson S., Herman Z.S., 1990. Lowering of serum cholesterol and triglycerides and modulation of divalent cations by dietary phytate. J. Appl. Nutr. 42, 18-22

Jenkins D.J.A., Wolever T.M.S., 1981. Slow release carbohydrate and trcatment of diabetes. Proc. Nutr. Soc. $40,227-233$

Jenkins D.J.A., Wolever T.M.S., Kalmusky J., Guidici S., Giordano C., Wong G.S., Bird J., Patten R., Hall M., Buckley G., Little J.A., 1985. Low glycemic index carbohydrate food in the management of hyperlipidemia. Amer. J. Clin. Nutr. 42, 604-612

Kamp D.W., Israbian V.A., Yeldandi A.V., Panos R.J., Gracefla P., Weitzmann S.A.,1995. Phytic acid, an iron helator, attenuates pulmonary inflammation and fibrosis in rats after intratracheal instillation of asbestos. 'loxicol. Pathol. 23, 689-695

Klevay L.M., 1973. Hypcrcholesterolcmia in rats produced by an increase in the ratio of zinc to copper ingested. Amer. J. Clin. Nutr. 26, 1060-1068

Klevay L.M., 1975. Coronary heart disease: the zinc-copper hypothesis. Amer. J. Clin. Nutr. 28, 764-770

Klevay L.M.,1977. Hypocholesterolemia due to sodium phytate. Nutr. Rep. Int. 15, 587-589

Knuckles B.F., Kuzmicky D.D., Betschart A.A., 1985. Fffect of phytate and partially hydrolyzed phytate on in vitro protein digestibility. J. Food Sci. 50, 1080-1082

Kratzer F.H., 1965. Soybean protein-minera! inter-relationships. Fed. Proc. Amer. Soc. Exp. Biol. $24,1498-1506$ 
Liddle R.A., Goldfine 1.E., Williams J.A., 1984. Bioassay of plasma cholecystokinin in rats. Effects of food, trypsin inhibitor and alcohol. Gastroenterology 87, 524-549

Maga J.A., 1982. Phytate: its chemistry, occurrence, food interactions, nutritional significance, and methods of analysis. J. Agric. Food Chem. 30, 1-9

Malek R.S., Boyce W.H., 1973. Intranephronic calculosis: its signifcance and relationship to matrix in nephrolithiasis. J. Urol. 132, 1140-1145

Menniti F.S., Miller R.N., Putncy J.W., Shears S.B., 1992. Turnover of inositol polyphosphate pyrophosphates in pancreatoma cells. J. Biol. Chem. 268, 3850-3856

Modlin M., 1980. Urinary phosphorylated inositols and renal stone. The Lancet, 1113-1114

Mroz Z., Jongbloed A.W., Kemme P.A., 1994. Apparent digestibility and retention of nutrients bound to phytate complexes as influenced by microbial phytasc and feeding regimen in pigs. J. Anim. Sci. 72, 126-132

Nahapetian A., Young V.R., 1980. Metabolism of ${ }^{14} \mathrm{C}$-phytate in rats: effect of low and high dietary calcium intakes. J. Nutr. 110, 1458-1472

Nasi J.M., Helander E.H., Partanen K.H., 1995. Availability for growing pigs of minerals and protein of a high phytate barlcy-rapeseed meal diet treated with Aspergillus niger phytase or soaked with whey. Anim. Feed Sci. Tcchnol. 56, 83-98

Nelson R.L., 1992. Dietary iron and colorectal cancer risk. Free Radical Biol. Med. 12, 161-165

Norris F.A., Ungewickell E., Majerus P.W., 1995. Inositol hexakisphosphate binds to clathrin assembly protcin 3 (AP-3/AP180) and inhibits clathrin cage assembly in vitro. J. Biol. Chem. $270,214-217$

O'Dell B.L., Boland A., 1976. Complexation of phytate with proteins and cations in corn germ and oil seeds. J. Agric. Food Chem. 24, 804-808

Ohkawa T., Ebisuno S., Kitagawa M., Morimoto S., Miyazaki Y., 1983. Rice bran treatment for hipercalciuric patients with urinary calculous disease. J. Urol. 129, 1009-1012

Ohkawa T., Ebisuno S.. Kitagawa M., Marimoto S., Miyazaki Y., Yasukawa S., 1984. Rice bran treatment for patients with hipercalciuric stones: experimental and clinical studies. J. Urol. I32, 1140-1145

Palczcwski K., Pulvermuller A., Buczylko J., Gutmann C., Hofmann K.P., 1991. Binding of inositol phosphates to arrestin. FEBS 295, 195-199

Prasad A.S., Oberleas D., 1974. Thymidine kinase activity and incorporation of thimidin into DNA in zinc-defcient tissue. J. Lab. Clin. Med. 83, 634-639

Sakamoto K., Venkatraman G., Shamsuddin A.M., 1993. Growth inhibition and differentiation of HT-29 cells in vitro by inositol hexaphosphate (phytic acid). Carcinogenesis 14, 1815-1819

Sakamoto K., Vucenik I., Shamsuddin A.M., 1993. [ $\left.{ }^{3} \mathrm{H}\right]$ Phytic acid (inositol hexaphosphate) is absorbed and distributed to various tissues in rats. J. Nutr. 123, 713-720

Sandberg A.S., Carlsson N.G., Svanberg U., 1989. Effect of inositol tri-, tetr-, penta- and hexaphosphates on in vitro estimation of iron availability. J. Food Sci. 54, 159-161

Sandberg A.S., Larsen T., Sandstrom B., 1993. I Iigh dietary calcium level decreases colonic phytate degradation in pigs fed a rapeseed diet. J. Nutr. 123, 559-566

Shamsuddin A.M., Baten A., Laiwani N.D., 1992. Effect of inositol hexaphosphate on growth and differentiation in K-562 crythroleukemia cell line. Cancer Lett. 64, 195-202

Shamsuddin A.M., Lllah A.. 1989. Inositol hexaphosphate inhibits large intestine cancer in F 344 rats 5 months after induction by azoxymetane. Carcinogenesis 10, 625-629

Shamsuddin A.M., Yang G., 1995. Inositol hexaphosphate inhibits growth and induces differentiation of PC-3 human prostate cancer cells. Carcinogenesis 16, 1975-1979

Singh M., Krikorian A.D., 1982. Inhibition of trypsin activity in vitro by phytate. J. Agric. Food Chem. 30, 799-800 
Sognen E., 1965. Apparent depression in the absorption of strychnine, alcohol and sulphanilamide after oral administration of sodium fluoride, sodium oxalate, tetracemin and sodium phytate. Acta Pharm. Toxicol. 22, 8-14

Szkudelski T., 1995. Ilow does phytic acid decrease the absorption of elements in the digestive tract? J. Feed Anim. Sci. 4, 77-82

Szwergold B.S., Graham R.A., Brown T.R., 1987. Observation of inositol pentakis- and hexakis-phosphates in mammalian tissues by ${ }^{31} \mathrm{P}$ NMR. Biochem. Biophys. Res. Commun. 149, 874-881

Thomas W.C., Tilden M.T., 1972. Inhibition of mineralization by hydrolysis of phytic acid. Johns Hopkins Med. J. 131, 133-136

Thompson L.U., Button C.L., Jenkins D.J.A., 1987. Phylic acid and calcium affect the in vitro rate of nave bean starch digestion and blood glucose response in humans. Amer. J. Clin. Nutr. 46, 467-473

Thompson L.U., Serraino M.R., 1986. Effect of phytic acid reduction on rapeseed protein digestibility and amino acid absorption. J. Agric. Food Chem. 34, 468-469

Thompson I.U., Zhang I., 1991. Phytic acid and minerals: effect on early markers of risk for mammary and colon carcinogenesis. Carcinogenesis 12, 2041-2045

Vallejo M., Jackson T., Lightman S, Hanlcy M.R., 1987. Occurrence and cxtracellular actions of inositol pentakis- and hexakisphosphate in mammalian brain. Nature 330, 656-658

Volgmaier S.M., Keen J.H., Murphy J.E., Ferris C.D., Prestwich G.D., Snyder S.H., Theibert A.B., 1992. Inositol hexakisphosphate receptor identified as the clathrin assembly protein AP-2. Biochem. Biophys. Res. Commun. 187, 158-163

Vucenik I., Sakamoto K., Bansal M., Shamsuddin A.M.. 1993. Inhibition of rat mammary carcinogenesis by inositol hexaphosphate (phytic acid). A pilot study. Cancer Lett. 75, 95-102

Vucenik I., Shamsuddin A.M., 1994. [ ${ }^{3} \mathrm{H}$ ]Inositol hexaphosphate (phytic acid) is rapidly absorbed and metabolized by murine and human malignant cells in vitro. J. Nutr. 124, 861-868

Vucenik I., Yang G., Shamsuddin A.M., 1995. Inositol hexaphosphate and inositol inhibit DMBAinduced rat mammary cancer. Carcinogenesis $16,1055-1058$

Wise A., 1983. Dietary factors determining the biological activities of phytate. Nutr. Abstr. Rev. 59, $791-806$

Wise R.O., Kark A.E., 1961. Urinary calculi and serum calcium levels in $\Lambda$ fricans and Indians. S. Afr. Med. J. 35, 47-50

Yoon J., Thompson L.U., Jenkins J.A., 1983. The effect of phytic acid on the in vitro rate of starch digestion and blood glucose response. Amer. J. Clin. Nutr. 38, 835-842

\section{STRESZCZENIE}

\section{Kwas fitynowy - róẋne aspekty działania na organizm}

Kwas fitynowy wystẹpuje $w$ ziarnach i nasionach wielu gatunków roślin. Spożywanie go z pokarmem może powodować ograniczenic absorpcji wielu mikro- i makroelementów z przewodu pokarmowego. Interakcje tego związku ze składnikami znajdującymi się w treści przewodı pokarmowego mogą ograniczać trawienie białka i skrobi. Prowadzi to do zmniejszenia retencji azotu i wywoluje łagodnicjszy wzrost glikemii w okresic absorpcyjnym. Kwas fitynowy ma równicż właściwości preciwnowolworowe. może zapobiegać tworłeniu się kamieni nerkowych oraz. 
niektórym chorobom serca. Syntezę tego związku stwierdzano również w tkankach ssaków oraz wykazano jego zdolność do specyficznego wiązania z niektórymi białkami w komórkach.

W niniejszej pracy przedstawiono pokrótce najważniejsze efekty działania kwasu fitynowego w organizmie. W oparciu o dane literaturowe podjęto też próbę wyjaśnienia mechanizmów, poprzez które związek ten wywołuje wspomniane zmiany. 